\title{
Synthesis of a Peptide with Delicious Taste
}

\author{
Yoshio Yamasaki and Kazuyuki MaEKaWA* \\ Department of Public Health, Okayama University, Medical School, \\ Okayama and Fukuoka Junior College of Social Welfare \\ and Nursery, Tagawa-shi, Fukuoka, Japan
}

Received June 25, 1979

\begin{abstract}
In order to confirm the primary structure of a delicious peptide which was isolated from extracts of the beef meat, a peptide, H-Lys-Gly-Asp-Glu-Glu-Ser-Leu-Ala-OH, was synthetized. Both of the synthetized peptide and isolated one were identical as shown in many respects.
\end{abstract}

We had reported the isolation of a peptide with delicious taste from extracts of the beef meat treated with papain. ${ }^{1)}$ Its primary structure was also proposed. ${ }^{2}$ The present paper deals with the confirmation of that structure by the synthesis.

An outline of the synthetic route was illustrated briefly in Fig. 1. Amino groups were protected with $t$-butoxyl (Boc) or carbobenzoxyl $(Z)$ group, while carboxyl groups were converted to benzyl (Bzl) or methyl (Me) ester. Until a hexapeptide from the carboxyl terminus (Ala) a chain was stepwise elongated. Lastly Z-Lys(Z)-Gly was coupled with the hexapeptide. The condensation reaction was carried out by use of alkyl chloroformate. ${ }^{3)}$ The intermediate in each step was checked by TLC, high voltage ionophoresis, elemental analysis, and sensory test.

Furthermore, the relationship between an appearance of the delicious taste and structure was discussed about some related peptides.

\section{EXPERIMENTALS}

The hydrolysis of peptide was carried out with $6 \mathrm{~N} \mathrm{HCl}$ at $110^{\circ} \mathrm{C}$ for $24 \mathrm{hr}$ in a sealed evacuated tube. Amino acid analyses were performed by a Hitachi Model 034 amino acid analyzer. Melting points were determined on a capillary melting point apparatus and were uncorrected. The benzyloxycarbonyl amino acids and benzyl ester of amino acids used were prepared usually. Other amino acid derivatives were purchased from the Protein Research Foundation (Osaka). All of other chemicals used were of reagent grade available from the commercial sources.

The high voltage paper electrophoresis was carried out under the following two different conditions on the Toyo filter paper No. 51: (a), pH 6.5 (pyridine: AcOH: $\left.\mathrm{H}_{2} \mathrm{O}=10: 0.4: 90\right), 2000 \mathrm{~V}(50 \mathrm{~V} / \mathrm{cm}), 90 \mathrm{~min}$. (b), pH 3.6 (pyridine: $\mathrm{AcOH}: \mathrm{H}_{2} \mathrm{O}=1: 10: 289$ ), $2000 \mathrm{~V}$ $(50 \mathrm{~V} / \mathrm{cm}), 90 \mathrm{~min}$.

Solvent systems for thin layer chromatography were as follows: $\mathrm{A}=$ chloroform-acetic acid-methanol $(85: 10: 5), \quad B=n$-butanol-acetic acid-water $(4: 1: 1)$, $\mathrm{C}=n$ - butanol - acetic acid - pyridine - water (15:3:10: 12), $\mathrm{D}=n$-butanol-acetic acid-ethyl acetate-water $(1$ : $1: 1: 1)$.

The judgement of the racemization was performed by adopting carboxypeptidase $\mathrm{A}$.

\section{Syntheses of peptides.}

Benzyl ester of N-t-butoxycarbonyl-O-benzyl-Lseryl-L-leucyl-L-alanine (I). A solution of $\mathrm{N-t}$ butoxycarbonyl-O-benzyl-L-serine ${ }^{4}(5.0 \mathrm{~g})$ in toluene $(50 \mathrm{ml})$ was cooled to $-10^{\circ} \mathrm{C}$ and treated in turn with triethyl amine $(1.71 \mathrm{~g})$ and ethyl chloroformate $(1.83 \mathrm{~g})$. After $7 \mathrm{~min}$, a solution of L-leucyl-Lalanine benzyl ester hydrochloride ${ }^{5)}(5.86 \mathrm{~g})$ in chloroform $(50 \mathrm{ml})$ with triethylamine $(1.71 \mathrm{~g})$ was added to it and stirred for few min at $-10^{\circ} \mathrm{C}$, followed to stand overnight at room temperature. The solution was washed with water, $5 \%$ sodium bicarbonate and water again, then dried with sodium sulfate and evaporated. The residue was crystallized from ethyl acetate-petroleum ether. Yield, $6.7 \mathrm{~g}(67.7 \%), \mathrm{mp}$ $125 \sim 127^{\circ} \mathrm{C}$.

O-Benzyl-L-seryl-L-leucyl-L-alanine benzyl ester hydrochloride (II). The compound I (5.2 g) dissolved in dioxane $(25 \mathrm{ml})$ was added to $4 \mathrm{~N} \mathrm{HCl} /$ dioxane $(70 \mathrm{ml})$ cooled beforehand and allowed to stand for $1 \mathrm{hr}$ at room temperature. The solvent was removed below $35^{\circ} \mathrm{C}$ and the residue was dried in a vacuum desiccator over sodium hydroxide for $16 \mathrm{hr}$. The dried residue was recrystallized from chloroform. Yield, $4.5 \mathrm{~g}(97.4$ $\%$, mp $114 \sim 116^{\circ} \mathrm{C}, \operatorname{Rf} 0.28$ (solvent $\mathrm{A}$ ). 


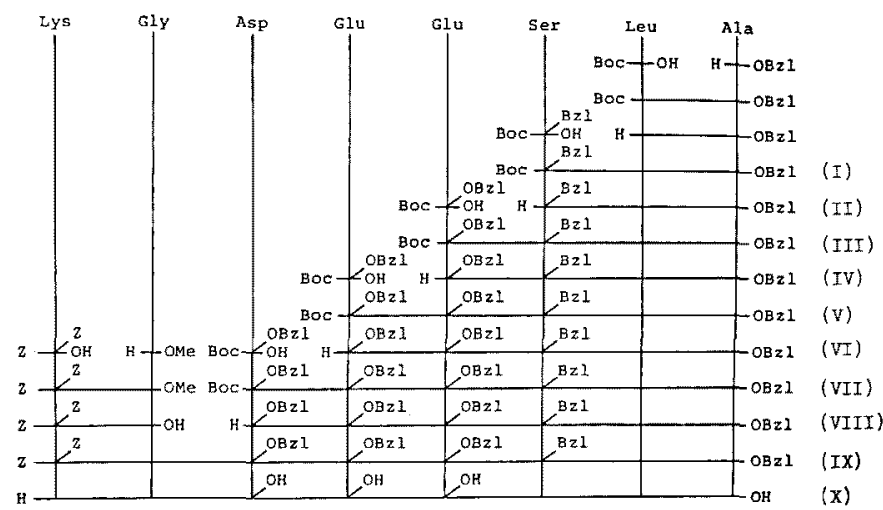

FIG. 1. Syntheses of Peptides.

$N-t$-Butoxycarbonyl-r-benzyl-L-glutamyl-O-benzylL-seryl-L-leucyl-L-alanine benzyl ester (III). A solution of $N$ - $t$-butoxycarbonyl- $\gamma$-benzyl-L-glutamic acid ${ }^{83}$ $(3.0 \mathrm{~g})$ and the compound II $(3.7 \mathrm{~g})$ were mixed and worked up in the usual fashion to obtain an oil, which was crystallized from etbyl acetate-petroleum ether. Yield, $5.4 \mathrm{~g}(93.7 \%), \mathrm{mp} 138 \sim 140^{\circ} \mathrm{C}$. Anal. calcd. for $\mathrm{C}_{43} \mathrm{H}_{58} \mathrm{~N}_{4} \mathrm{O}_{10}(788.95): \mathrm{C}, 65.46 ; \mathrm{H}, 7.15 ; \mathrm{N}, 7.10$, found:C, 65.39; $\mathrm{H}, 7.18 ; \mathrm{N}, 7.27$.

$\gamma$ - Ber.zyl-L - glutamyl - O - benzyl-L - seryl-L-leucyl-Lalanine benzyl ester hydrochloride (IV). Compound III $(4.7 \mathrm{~g})$ was allowed to stand with $4 \mathrm{~N} \mathrm{HCl} /$ dioxane $(50 \mathrm{ml})$ for $1 \mathrm{hr}$ at room temperature. The solvent was removed and the residue was triturated with ether to yield a solid $(4.3 \mathrm{~g}, 98.5 \%) \mathrm{mp} 162 \sim 165^{\circ} \mathrm{C}$. Amino acid analysis: Ala, 1.09; Glu, 0.98; Leu, 1.14; Ser, 0.63 .

$N-t$ - Butoxycarbonyl- $\gamma$ - benzyl-L - glutamyl- $\gamma$ - benzyl$\mathrm{L}$-glutamyl-O-benzyl-L-seryl-L-leucyl-L-alanine benzyl ester (V). $\quad N$ - $t$-Butoxycarbonyl- $\gamma$-benzyl-L-glutamic acid $(1.92 \mathrm{~g})$ was treated with the compound IV $(4.07 \mathrm{~g})$, triethylamine $(1.16 \mathrm{~g})$ and ethyl chloroformate $(0.62 \mathrm{~g})$ in toluene $(20 \mathrm{ml})$. The residue was crystallized from absolute ethanol. Yield $3.2 \mathrm{~g}(56.6 \%)$ : mp $181 \sim 183^{\circ} \mathrm{C}$. Anal. calcd. for $\mathrm{C}_{65} \mathrm{H}_{67} \mathrm{~N}_{8} \mathrm{O}_{13}$ (1008. 19): C, 65.52; H, 6.94; N, 6.93, found: $C, 65.20$; $\mathrm{H}, 6.90 ; \mathrm{N}, 6.89$.

$\gamma$-Benzyl-L-glutamyl- $\gamma$ - benzyl-x-glutamyl-O-benzyl$\mathrm{L}-\operatorname{sery}$-L-leucyl-L-alanine benzyl ester hydrochloride (VI). The compound V (2.2 g) was allowed to stand with $4 \mathrm{~N} \mathrm{HCl} /$ dioxane $(30 \mathrm{ml})$ for $1 \mathrm{hr}$ at room temperature. The solvent was removed and the residue was dried in a vacuum desiccator over sodium hydroxide. Yield, $2.0 \mathrm{~g}(97 \%)$ : mp $182 \sim 184^{\circ} \mathrm{C}$ (decomp.); $R f$ 0.89 (solvent $\mathrm{B}$ ). Amino acid analysis: Ala, 0.92; Glu, 2.00; Leu, 1.00; Ser, 0.64.

$N-t$ - Butoxycarbonyl - $\beta$ - benzyl-L - aspartyl-r-benzylL-glutamyl- - -benzyl-L-glutamyl-O - benzyl - L - seryl-Lleucyl-L-alanine benzyl ester (VII). $N$-t-Butoxycarbonyl- $\beta$-benzyl-L-aspartic acid $^{7)}(0.69 \mathrm{~g})$ in toluene
$(10 \mathrm{ml})$ was allowed to react with the compound VI $(2.0 \mathrm{~g})$, in the presence of triethylamine $(0.44 \mathrm{~g})$ and ethyl chloroformate $(0.23 \mathrm{~g})$ in chloroform $(20 \mathrm{ml})$. The solvent was removed and the residue was recrystallized from $80 \%$ methanol to yield a colorless solid $\left(2.3 \mathrm{~g}, 87.1 \%\right.$ ): $\mathrm{mp} 200 \sim 202^{\circ} \mathrm{C}$ (decomp.). Anal. calcd. for $\mathrm{C}_{86} \mathrm{H}_{80} \mathrm{~N}_{8} \mathrm{O}_{16}(1213.40): \mathrm{C}, 65.33: \mathrm{H}, 6.65$ : $\mathrm{N}, 6.93$ : found, $\mathrm{C}, 65.05: \mathrm{H}, 6.61 ; \mathrm{N}, 6.90$.

$\beta$-Benzyl-L-aspartyl- $\gamma$ - benzyl-L-glutamyl - $\gamma$ - benzylL-glutamyl-O-benzyl-L-seryl-L-leucyl-L-alanine benzyl ester hydrochloride (VIII). The compound VII $(1.95 \mathrm{~g})$ was allowed to stand with $4 \mathrm{~N} \mathrm{HCl} /$ dioxane $(30 \mathrm{ml})$ for $1 \mathrm{hr}$ at room temperature. The solvent was removed and the residue was dried in a vacuum desiccator over sodium hydroxide. Yield, $1.84 \mathrm{~g}(99.5 \%): \mathrm{mp} \mathrm{188 \sim}$ $189^{\circ} \mathrm{C}$ (decomp.); Rf 0.89 (solvent B). Amino acid analysis: Ala, 1.01; Asp, 0.71; Glu, 2.14; Leu, 1.05; Ser, 0.43 .

$\alpha$, e-Dicarbobenzoxy-L-lysyl-glycyl- $\beta$-benzyl-L-aspartyl- $\gamma$-benzyl-L-glutamyl- $\gamma$-benzyl-L-glutamyl-O-benzylL-seryl-L-leucyl-L-alanine benzyl ester (IX). $\quad \alpha, \varepsilon-$ Dicarbobenzoxy-L-lysyl-glycine ${ }^{8)}(0.8 \mathrm{~g})$ in THF $(10 \mathrm{ml})$ was treated with the compound VIII $(1.8 \mathrm{~g})$, triethylamine $(0.32 \mathrm{~g})$ and ethylchloroformate $(0.17 \mathrm{~g})$ in chloroform $(15 \mathrm{ml})$. After usual treatment, the solid material was recrystallized from methanol $(1.45 \mathrm{~g}$, $72.3 \%$ ):mp $219 \sim 221^{\circ} \mathrm{C}$ (d). Anal. calcd. for $\mathrm{C}_{85} \mathrm{H}_{89}-$ $\mathrm{N}_{2} \mathrm{O}_{20}(1566.78): \mathrm{C}, 65.16 ; \mathrm{H}, 6.37 ; \mathrm{N}, 8.05$, found: C, 64.93; H, 6.33; N, 8.01.

$\mathrm{L}-$ Lysyl-glycyl-L - aspartyl-L - glutamyl- L - glutamylL-seryl-L-leucyl-L-alanine (X). A solution of the octapeptide $(0.7 \mathrm{~g})$ in methanol $(100 \mathrm{ml})$ was hydrogenated in the presence of $10 \%$ palladium black catalyst $(300 \mathrm{mg})$ for $5 \mathrm{hr}$. After filtration, the solution was purified by treatment of active carbon. The solvent was evaporated to leave a solid mass, which was dried in a vacuum desiccator over sodium hydroxide. Yield, $0.35 \mathrm{~g}(88.3 \%)$, mp $182 \sim 184^{\circ} \mathrm{C}$, $[\alpha]_{\mathrm{D}}^{25}=-48.0^{\circ}$ (water). Amino acid analysis: Ala, 0.98; Asp, 0.99; Glu, 2.04; Gly, 0.90; Leu, 1.05; Lys, 


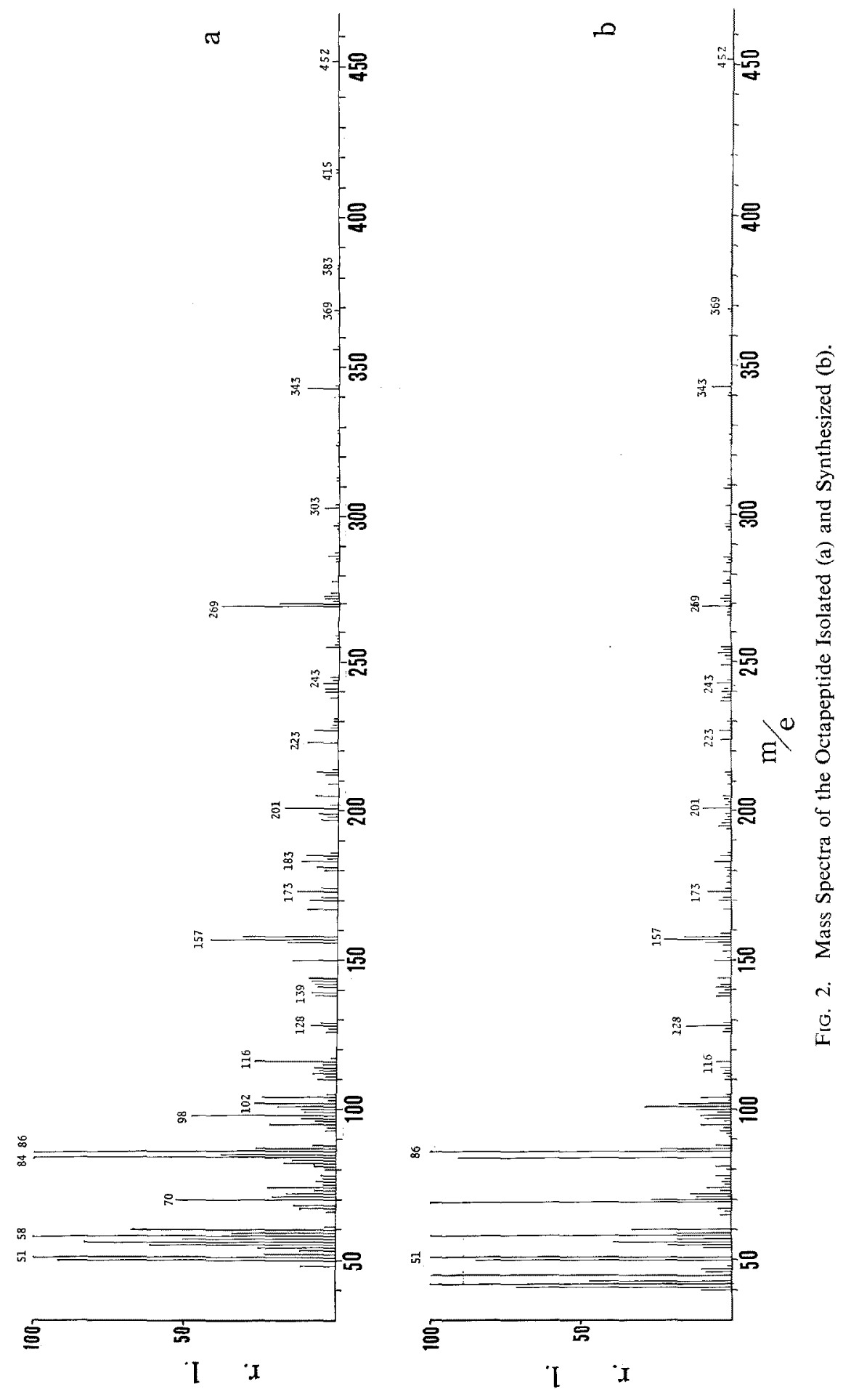


0.56 ; Ser, 0.92. As a result of the carboxypeptidase A digestion, it was clarified that the synthesized peptide did not contain racemic compounds.

Syntheses of some peptides related to the octapeptide $\alpha, \beta$-Dibenzyl ester of $\alpha, \varepsilon$-dicarbobenzoxy-L-lysylglycyl-L-aspartic acid. $\quad \alpha, \varepsilon$-Dicarbobenzoxy - L-lysylglycine $(1.0 \mathrm{~g})$ in dioxane $(10 \mathrm{ml})$ was treated with $N$-tosylated $\alpha, \beta$-dibenzyl ester of L-aspartic acid ${ }^{8)}$ $(1.09 \mathrm{~g})$, triethylamine $(0.42 \mathrm{~g})$ and ethylchloroformate $(0.21 \mathrm{~g})$ in chloroform $(30 \mathrm{ml})$. The solvent was removed and the residue was recrystallized from chloroformpetroleum ether and ethyl acetate-petroleum ether to yield a colorless solid $(1.1 \mathrm{~g}, 69.6 \%): \mathrm{mp} 107 \sim 108^{\circ} \mathrm{C}$. Amino acid analysis: Asp, 1.02; Gly, 1.00; Lys, 0.83.

$a, \varepsilon$-Dicarbobenzoxy-L-lysyl-glycyl-O-benzyl-L-serylL-leucyl-L-alanine benzyl ester. $\quad \alpha, \varepsilon$-DicarbobenzoxyL-lysyl-glycine $(216 \mathrm{mg})$ in THF $(3 \mathrm{ml})$ was treated with the compound II $(223 \mathrm{mg})$, triethylamine $(86 \mathrm{mg})$ and ethylchloroformate $(46 \mathrm{mg})$ in chloroform $(3 \mathrm{ml})$. The solvent was removed and the residue was recrystallized from ethyl acetate-petroleum ether to yield a colorless solid $\left(291 \mathrm{mg}, 69.4 \%\right.$ ): $\mathrm{mp} 164 \sim 166^{\circ} \mathrm{C}$. Anal. calcd. for $\mathrm{C}_{50} \mathrm{H}_{82} \mathrm{~N}_{8} \mathrm{O}_{11}(923.08): \mathrm{C}, 65.06 ; \mathrm{H}$, $6.77 ; \mathrm{N}, 9.10$, found: $\mathrm{C}, 64.91 ; \mathrm{H}, 6.78 ; \mathrm{N}, 9.03$. Amino acid analysis: Ala, 0.95; Gly, 1.00; Leu, 1.02; Lys, 0.56; Ser, 0.53 .

In order to remove the protective group, each of the products synthetized was dissolved in methanol containing acetic acid and palladium black, and hydrogen gas was introduced into the suspension with stirring for $5 \mathrm{hr}$. The filtrate freed from the catalyst was concentrated under reduced pressure and lyophilized.

Sensory test. Each of the samples was dissolved in distilled water to obtain $5 \%$ solution. For the sensory evaluation, $2.0 \mathrm{ml}$ of solution was examined through the sensory faculties of 5 persons having a developed sense of taste. Furthermore, in order to compare accurately, a complete scale of individual taste such as sweetness, sour, bitterness, astringency, and palatable taste covering the whole taste scale was carefully examined and expressed numerically. Then, assuming that the evaluated value of the octapeptide was a palatable standard, the sensory evaluation of other peptides was enumerated.

Mass spectrometry:-Both of the isolated and synthesized peptides were submitted to mass spectrometry after being esterified, and trifluoroacetylated. ${ }^{10}$ The mass spectra were determined with a JMS-O1SG mass spectrometer, Japan Electron Optics Lab., by use of a direct inlet (source temperature $200^{\circ} \mathrm{C}$; beam energy of $75 \mathrm{eV}$ ).

\section{RESULTS AND DISCUSSION}

In the mass spectra of isolated and synthesized peptides, we could not detect the parent peak, but recognize only fragments ions smaller than half of the whole molecule. Therefore, it is difficult to draw a conclusion about the whole figure. However, the mass fragmentation of both peptides showed almost the same pattern as shown in Fig. 2. This may support their identity.

The high voltage paper electrophoresis as to the isolated peptide and synthesized one was carried out under the two different conditions $(a, b)$. As seen in Fig. 3 as an example, both peptides migrated at the same rate and showed a single spot. Under an-

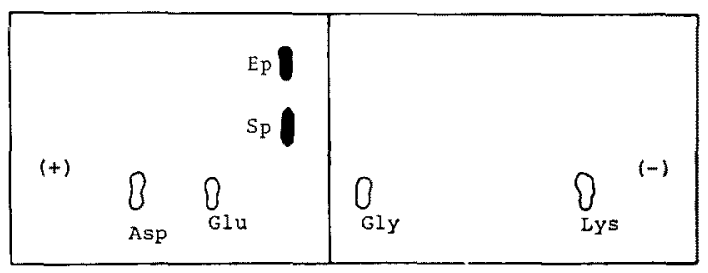

FIG. 3. Electropherogram of the Peptides

pH 6.5 (Pyr: AcOH: $\left.\mathrm{H}_{2} \mathrm{O}=10: 0.4: 90\right)$ 2,000 V $(50$ $\mathrm{V} / \mathrm{cm}), 3.3 \mathrm{~mA} / \mathrm{cm}, 90 \mathrm{~min}$, Toyo Filter paper No. 51 . Ep, extracted peptide; Sp, synthesized peptide.

Table I. Evaluation of Taste of Some Peptides Related to the Octapeptide

\begin{tabular}{|c|c|c|c|c|c|}
\hline Peptides $(50 \mathrm{mg} / \mathrm{ml})$ & Sweet & Sour & Bitter & Savory & Astringent \\
\hline Lys-Gly-Asp-Glu-Glu-Ser-Leu-Ala & 10 & 30 & 0 & 60 & 0 \\
\hline Asp-Glu-Glu-Ser-Leu-Ala & 5 & 60 & 2 & 10 & 15 \\
\hline Glu-Glu-Ser-Leu-Ala & 0 & 55 & 5 & 10 & 18 \\
\hline Glu-Ser-Leu-Ala & 0 & 44 & 3 & 5 & 32 \\
\hline Ser-Leu-Ala & 0 & 5 & 55 & 0 & 10 \\
\hline Lys-Gly $\quad$ Ser-Leu-Ala & 0 & 0 & 50 & 0 & 13 \\
\hline Lys-Gly-Asp & 0 & 0 & 0 & 0 & 0 \\
\hline Lys-Gly & 0 & 0 & 0 & 0 & 5 \\
\hline
\end{tabular}


other condition (b) both peptides behaved similarly as a single spot.

On a TLC (silica gel, Merck type G-60), both peptides showed same $R f$ values in the following solvent systems: solvent $\mathrm{C}, R f=$ 0.21 , solvent $\mathrm{D}, R f=0.28$.

A sensory evaluation of the isolated peptide and synthesized one showed the same result. Therefore, the primary structure of the delicious peptide was decided as the $X$.

In an attempt to know the structure necessary for a palatable taste, some sensory experiments were provided on peptides related to the octapeptide. As a result, as seen from Table 1, Lys-Gly-Asp-Glu-Glu-Ser-Leu-Ala was sour and palatable, whereas Asp-GluGlu-Ser-Leu-Ala and Glu-Glu-Ser-Leu-Alawere sour, astringent and mildly palatable. Glu-Ser-Leu-Ala was sour and astringent. Ser-Leu-Ala was bitter, Lys-Gly-Ser-Leu-Ala was also bitter and astringent.

From these facts, it is evident that a bitter principle located near the C-terminal is presumably weakend by the elongation of the peptide with acidic amino acids toward the N-terminal. On the other hand, the sour taste became markedly strong by this elon- gation. However, the sour taste is softened by Lys-Gly- residue of $\mathrm{N}$-terminal. By this procedure, the peculiar astringent taste of peptides will disappear concomitantly. On the whole, it is inferred that the octapeptide has a good taste like meat.

\section{REFERENCES}

1) Y. Yamasaki and K. Maekawa, Agric. Biol. Chem., 42, 1761 (1978).

2) Y. Yamasaki and K. Maekawa, Fifth Intern. Congr. Food Sci. Technology, Kyoto, Sep. 17-22, 1978, Abstracts, p. 186.

3) N. Izumiya and J. P. Greenstein, Arch. Biochem. Biophys., 52, 203 (1954).

4) E. Wünsch und A. Zwick, Chem. Ber., 97, 2497 (1964).

5) W. J. Polglase and E. L. Smith, J. Am. Chem. Soc., 71, 3081 (1949).

6) E. Schröder und E. Klieger, Ann. Chem., 673, 196 (1964).

7) E. Bayer, G. Jung and H. Hagenmeier, Tetrahedron, 24, 4853 (1968).

8) W. Grassmann und E. Wünsch, Chem. Ber., 91, 449 (1958).

9) N. Izumiya and S. Makisumi, J. Chem. Soc. Japan, 78, 1768 (1957).

10) F. Weygand und R. Geiger, Chem. Ber., 89, 647 (1956). 